\title{
Evaluation of the "Steps for Life" Personal and Social Skills Greek K-Curriculum
}

\author{
Ntina Kourmousi ${ }^{1}$, Maria Salagianni1 ${ }^{1},{\text { Kyriakoula } \text { Merakou}^{2}, \text { Chara Tzavara }^{3} \text {, Vasilios Koutras }}^{1}$ \\ ${ }^{1}$ Department of Early Childhood Education, University of Ioannina, Ioannina, Greece \\ ${ }^{2}$ Department of Public \& Administrative Health, National School of Public Health, Athens, Greece \\ ${ }^{3}$ Centre for Health Services Research, Department of Hygiene, Epidemiology and Medical Statistics, Medical School of National \\ and Kapodistrian University of Athens, Athens, Greece \\ Email: ^nkourmousi@sch.gr, msalagianni@yahoo.gr, vkoutras@cc.oui.gr, kmerakou@esdy.edu.gr, nkourmousi@sch.gr, \\ htzavara@med.uoa.gr
}

How to cite this paper: Kourmousi, N., Salagianni, M., Merakou, K., Tzavara, C., \& Koutras, V. (2017). Evaluation of the "Steps for Life" Personal and Social Skills Greek K-Curriculum. Creative Education, 8, 1912-1940.

https://doi.org/10.4236/ce.2017.812131

Received: August 11, 2017

Accepted: September 25, 2017

Published: September 28, 2017

Copyright () 2017 by authors and Scientific Research Publishing Inc. This work is licensed under the Creative Commons Attribution International License (CC BY 4.0).

http://creativecommons.org/licenses/by/4.0/

(c) (†) Open Access

\begin{abstract}
Background: The past few decades have seen a significant growth of research on socio-emotional skills development programs and on mental health education in schools since their key-importance has been well documented. This study presents the evaluation of "Steps for life", an open, question-based, annual, teacher-taught, mental health Greek K-curriculum, designed to improve personal and social skills in young students aged $4-6$. The curriculum uses classroom-appropriate methods such as dialoguing, story-telling, role-playing and diffusion in formal and hidden curriculum, while incorporating a considerable degree of parental involvement. Methods: The study was conducted in Greece during 2009-2010. The sample consisted of 998 kindergartners, with 518 of them forming the experimental group and 480 the control group. The questionnaire designed for the study consisted of items regarding demographics, of the Behavioural Academic Self-Esteem scale and of 8 more subscales, namely concentration of attention, participation and cooperation in the class, emotions' identification and management, physical and verbal aggressiveness control, victimization control, self-esteem, empathy, friendship skills, and problem solving. Its 96 -in total-items examined students' behaviors as exhibited in the school environment and as observed and rated by their teachers. It was administered pre and post intervention to both groups' educators. Results: The results suggest that both groups exhibited significant improvement in all investigated skills. As indicated by the regression analysis however, the intervention students showed significantly higher improvement in all targeted abilities except friendship skills. Conclusions: Our intervention improved more significantly almost all the taught skills, corroborating the findings of other researchers who found that similar approaches can improve
\end{abstract}


children's social and emotional skills. Therefore, it is important for schools and communities to identify and effectively implement evidence-based interventions.

\section{Keywords}

Personal and Social Skills Program, Mental Health Promotion Curriculum, K-Curriculum, Personal and Social Skills Scale for K-students 4 - 6, Steps for Life, Greek K-Students

\section{Introduction}

The development of social-emotional competence during early childhood is of critical importance as all child care-givers, educators and health professionals agree and as recent scientific research indicates (Blair, 2002). It is rooted in the goals of education (Sylva et al., 2004) despite another belief, curiously still co-existing in some countries like Greece on behalf both of parents (Kappatou, 2014) and teachers (Gouridou, 2015): the one that stresses the importance of academic skills' over the significance of social and emotional learning. But why should educators have to choose one over the other? After all, research has revealed that children who are socially and emotionally competent not only have higher confidence (Durlak et al., 2011; Haney \& Durlac, 1998; National Research Council and Institute of Medicine, 2000), communicate well (National Research Council and Institute of Medicine, 2000), form and maintain good relationships (Beelmann \& Lösel, 2006; National Research Council and Institute of Medicine, 2000), deal better with interpersonal problems (Durlak et al., 2011; Grossman et al., 1997; National Research Council and Institute of Medicine, 2000) and accomplish their tasks (National Research Council and Institute of Medicine, 2000), but do better in school as well (Ashdown \& Bernard, 2012; Bierman et al., 2008; Brackett et al., 2012; Durlak et al., 2011; National Research Council and Institute of Medicine, 2000).

Consequently, addressing the mental health needs of the young students is becoming a priority as Domitrovich, Cortes, \& Greenberg state (2007), recommended by the Joint Action on Mental Health and Well-being (Rampazzo et al., 2016), especially since evidence shows that disruptive behavior problems which appear in the early years can become more stable during adolescence (Campbell, 1995; Jones, Greenberg, \& Crowley, 2015; Kingston \& Prior, 1995; Moffitt et al., 1996). It seems obvious that schools-being the most appropriate settings for implementing interventions focusing on enhancing social and emotional skills (Rampazzo et al., 2016) can play a crucial role in children's psycho-social empowerment. Therefore, the past few decades have seen a significant growth of research and good practice on mental health promotion and prevention approaches in kindergarten settings, elementary and high-schools.

These approaches vary in their specific goals, target groups and theoretical basis. Regarding their goals, there are programs which aim to prevent aggressive- 
ness and problem behaviors (e.g. Farell et al., 2003; Gottfredson, Jones, \& Gore, 2002), substance use (e.g. Battistich et al., 2000; Botvin et al., 1990), and mental health problems (e.g. Greenberg, Domitrovich, \& Bumbarger, 2001; Merry et al., 2004), and others which generally seek to enhance socio-emotional skills (e.g. Ashdown \& Bernard, 2012; Bierman et al., 2008). Concerning their target groups, there are universal curricula which address a whole classroom (e.g. Forness et al., 1998), targeted ones that address students at risk of developing (e.g. Denham \& Burton, 1996; Miller-Heyl, MacPhee, \& Fritz, 1998) or already facing (e.g. Webster-Stratton \& Hammond, 1997) a mental health problem, and those that constitute both special-risk group and universal classroom interventions (e.g. Kusché \& Greenberg, 1994). Finally, as for their theoretical base, many of them find their roots in the Social Learning Theory, several rely on the Cognitive-Behavioral approach, some are based on the Systems Model, a few are designed within the Resilience framework, and others even borrow from the Psychoanalytic approach.

More importantly, regardless of their fundamental theoretical basis, quite many seem to fulfill their promises, since various meta-analyses show that they manage to improve children's emotional, social and coping skills (Diekstra \& Gravesteijn, 2008; Durlak et al., 2011; Durlak \& Wells, 1997; Payton et al., 2008; Wilson, Gottfredson \& Najaka, 2001). Specifically, SFL (Skills for Life), SES (Social Emotional Skills), SEL (Social Emotional Learning) and other Mental Health Promotion school-programs have been found to improve self-esteem (Haney \& Durlac, 1998; O’Mara et al., 2006) to prevent mental health problems (Greenberg, Domitrovich, \& Bumbarger, 2001), depression (Forness et al., 1998; Merry et al., 2004) and drug use (Faggiano et al. 2005), enhance emotion management and self-control (Barrett, 2004; Gansle, 2005; Kusché \& Greenberg, 1994), help children resolve interpersonal conflicts (Geller, 1999; Grossman et al., 1997; Kusché \& Greenberg, 1994; Shure \& Spivack, 1982) and maintain healthy relationships (Beelmann \& Lösel, 2006; Englander-Golden et al., 1989) and also reduce violent behavior (Catalano et al., 2002; Hahn et al., 2007; Wilson \& Lipsey, 2007; Wilson, Lipsey, \& Derzon, 2003).

Literature also suggests that preschool age is critical for the formation of social-emotional competence in children (Gansle, 2005; Mishara \& Ystgaard, 2006; Landy, 2009) with the higher impact of SEL interventions reported in the $4-7$ age group (Diekstra \& Gravesteijn, 2008; Gansle, 2005; Jones, Greenberg, \& Crowley, 2015). Pre-school settings which view educational and social development as complementary and of equal importance have been found to enhance children's all-round progress (Sylva et al., 2004). From an economical point of view, the return on human capital investment is higher when money is spent on the younger individuals as the Nobel Laureate in Economics Dr James Heckman (2000) states, insisting that we should invest in the very young by implementing approaches which support children's social and emotional development. Other researchers have also defended the argument that various SEL programs are a 
good financial investment (Durlak et al., 2011; Hawkins, Smith, \& Catalano, 2004; Belfield et al., 2015; Lee et al., 2012). However, most studies on primary prevention programs have been conducted on elementary and secondary education students as most meta-analyses show (Durlak et al., 2011; Campbell, 1995; Durlak \& Wells, 1997; Payton et al., 2008). The presented study examines the effectiveness of such an approach for early education: the "Steps for life" (Kourmousi, 2012) school-based, 25-week, universal, teacher-taught, mental health promotion kindergarten curriculum (K-curriculum), which is designed to improve personal and social skills in Greek kindergarten students (K-students) aged 4 - 6. Having taken into consideration that there were and still are no other social-emotional skills structured curricula created for use in Greek kindergartners and that the Greek Official Curriculum defines all students' social and emotional development as one of Greek education system's main goals $(\triangle \mathrm{E} \Pi \Pi \Sigma$, 2001; $\triangle \mathrm{E} \Pi \Pi \Sigma$, 2013), we designed and conducted the presented research, in order to identify a school-based approach which would enhance Greek K-students' personal and social skills. We hypothesized that K-students who would attend the "Steps for life" personal and social skills K-curriculum for one school year, would have greater improvement concerning the taught, targeted and investigated skills-namely concentration of attention, participation/cooperation in the class, empathy, self-esteem, emotions' identification and management, physical and verbal aggressiveness control, victimization control, friendship skills and problem solving-compared to the ones who would attend the existing curriculum.

\section{The "Steps for Life" Program}

\subsection{Description of the Program's Content}

"Steps for Life" is a personal and social skills development program designed for students of Greek kindergartens, having taken into account knowledge offered by various SES and SEL programs, approved by WHO and SAMHSA (e.g. Barrett, 2004; Borba, 1989; Botvin, 1998; Committee for Children, 2002; Kusché \& Greenberg, 1994; Shure, 2000; TACADE/Lions, 1990). The program is currently implemented in hundreds of kindergartens throughout the country, after having been approved by the Greek Ministry of Education (150320 Г1/15.10.2013) and the Greek Educational Policy Institute (A a program which addresses Greek kindergartners, its content transcends cultural context since it teaches skills for life, which-as suggested by WHO regarding Life Skills Education-aim to enhance adaptive and positive behavior and render children capable of dealing effectively with the demands and the challenges of everyday life (WHO, 2001).

The "Steps for Life" program is designed to be implemented within the Greek Official Curriculum. In the Greek educational context kindergarten is part of the primary education and it is obligatory for students aged 5 - 6 and optional for children aged 4 - 5. Children under that age, namely 0 - 4, can attend nurseries 
which constitute different settings, do not have official curricula and are not under the responsibility of the Ministry of Education. Kindergarten classes operate independently to a point, and each teacher submits her/his own daily progra-which has to be in line with the Official Greek Curriculum-for approval to the School Counselor responsible for the educational prefecture to which the school belongs.

The "Steps for Life" annual universal K-curriculum contains 50 whole-day lessons conducted twice a week. Its material includes: a) the Teacher's Manual including the theoretical basis and specific implementation instructions; $b$ ) the structured and analytical Lesson Guide ensuring an easy implementation; c) 3 hand-puppets used to introduce most of the lessons and demonstrate the taught skills; d) 96 pictures used to initiate discussion at most lessons; and e) the Letters to the Family which inform parents of the newly taught skills and provide them with specific instructions and indicative ways of dialoguing, thus supporting the continuation of the child's learning at home.

The program's 50 lessons are divided into four modules: a) adaptation period activities; b) instruction of basic concepts; c) emotions' identification and management; and d) problem solving. Each lesson includes: 1) the definition of the skill to be taught; 2) information about it; 3) the goals of the lesson; 4) specific instructions for its teaching; 5) the materials which will be needed; 6) the way of introducing it to the students; 7) the discussion, including all questions needed to be asked fully formulated; 8) the role-playing scenarios; 9) supplementary activities and games (for the day the lesson is taught and also for the following days); 10) dissemination in the formal curriculum (namely connection of the taught skills with: a. language and literacy through proverbs, poetry, literature etc.; b. mathematic concepts like categorization, classification, etc.; c. social studies; d. environmental studies; e. computer lessons; f. fine arts; g. physical education through psychomotor and team games, etc.); 11) connection of the taught skills with the hidden curriculum (by the term we refer to the unofficial lessons, values, and perspectives that students learn in school during free-activity time, break-time, and lunch time) through indicative dialoguing using real-life situations; and 12) the letter to be sent to each student's family, describing the new knowledge and the way it was taught, also providing care-givers with suggestions and instructions on how to enhance it. The suggested activities of each lesson which are realized every day until the next lesson is taught, together with the 4 repetition lessons included in the program, ensure that even students who are absent during one or more lessons will "pick up" the skills during the following days.

\subsection{Aim and Theoretical Basis of the Program}

The "Steps for Life" K-program aims to enhance students' self-esteem, empathy, and personal and social skills, with an emphasis on emotion management and problem solving. Regarding its theoretical underpinning we argue that it brings together many important elements and strategies from different approaches: As 
a health education program, it has roots on Social Learning Theory (Bandura, 1997), since it includes student's attempt (through role-playing), teacher's modeling of the taught skills, and feedback providing, until the learning is achieved. As a program almost solely taught by questions, encouraging children to think and problem solve by estimating consequences and by generating alternative solutions, it is significantly grounded in the cognitive approach of Arend, Gove, and Sroufe (1979) and in the work of Shure and Spivack (1982). As a program aiming at empowering the students by simultaneously changing teachers' (through detailed instructions and guidelines) and parents' (through guidance letters and actual involvement in continuous learning) approaches, it draws from the Eco-Behavioral Systems Model (Weissberg, Caplan, \& Sivo, 1989). As it prompts children to explore their experiences and learn through the process of pleasant discovery, it incorporates elements from the Psychoanalytic theory. Finally but as importantly, the way teachers are encouraged to unconditionally accept their students, actively listen to them and encourage them to find their own solutions to their problems, would connect "Steps for Life" with Carl Rogers' (1998) person-centered humanistic approach.

Moreover, in the "Steps for Life" approach there is no didacticism. Knowledge is offered almost solely by the students who are guided to reach it through open questions. Conclusions are also drawn by the children themselves, for themselves, and all differences of opinion are well-respected. Following a specific structure which the "Steps for Life" program proposes for safe emotion teaching, a frame is provided in Table 1 concerning the stages of the discussion and including some indicative questions.

In summary, the program does not seek to teach children 'what to do' or 'how to behave'. Instead, it focuses on encouraging them to think and decide for themselves after having explored facts and options.

\section{Materials and Methods}

\subsection{Participants}

The evaluation of the "Steps for Life" program implementation took place in the school year of 2009-2010, in the prefecture of Viotia which was chosen because it borders the prefecture of Greece's capital and consists of urban, semi-urban, industrial and agricultural areas as well, thus representing all country's socioeconomic groups of inhabitants (Hellenic Statistical Authority, 2001).

Seventy-nine kindergarten teachers (K-teachers), namely about $70 \%$ of $\mathrm{Vi}$ otia's prefecture total kindergarten-teacher population, volunteered to participate in our study. Their 998 students formed our sample. Having promised that the control group teachers would receive gratis both the package of the program and the training at the beginning of the next school year, we insisted on a draw between them so that the study would be randomized. Forty became the experimental group's teachers with their 518 students forming the experimental group who would attend the "Steps for Life" program. Thirty nine became the control group's teachers with their 480 students forming the control group-who 
Table 1. "Steps for Life" course discussion structure for safe emotion's teaching.

\begin{tabular}{|c|c|}
\hline Teaching stages & Indicative questions asked by the teacher \\
\hline $\begin{array}{l}\text { 1. Naming the } \\
\text { feeling }\end{array}$ & $\begin{array}{l}\text { How do you think the child in this picture feels? } \\
\text { What is the name of the feeling? }\end{array}$ \\
\hline $\begin{array}{l}\text { 2. External } \\
\text { recognition }\end{array}$ & $\begin{array}{l}\text { How can you tell what he/she feels? How are the eyes and the eyebrows? } \\
\text { What about the mouth, or the color of the face? Etc. }\end{array}$ \\
\hline $\begin{array}{l}\text { 3. Internal } \\
\text { recognition }\end{array}$ & $\begin{array}{c}\text { Do you remember a time when you also felt ... (that way)? What did it feel like } \\
\text { inside your body? } \\
\text { Did it feel warm or cold? Did it make your body feel tense or lose? How was your } \\
\text { heart beating? Etc. }\end{array}$ \\
\hline $\begin{array}{l}\text { 4. Causes of the } \\
\text { feeling/Factors }\end{array}$ & $\begin{array}{l}\text { What things usually make you feel ... (that way)? } \\
\text { (And writing down all answers) Do these things make all of you feel the same way? } \\
\text { So, do you think different people have different feelings for the same thing? Why } \\
\text { do you think that is? }\end{array}$ \\
\hline $\begin{array}{l}\text { 5. Usual behaviors } \\
\text { for the expression } \\
\text { of the feeling }\end{array}$ & $\begin{array}{l}\text { What do you usually do when you feel ... (that way)? } \\
\text { What else? }\end{array}$ \\
\hline $\begin{array}{l}\text { 6. Estimation of } \\
\text { these behaviors' } \\
\text { consequences }\end{array}$ & $\begin{array}{l}\text { (After having written down all the given answers to the previous question on the } \\
\text { left side of the board, the teacher draws arrows next to each reported behavior and } \\
\text { asks what would possibly happen after applying the behavior) What would possi- } \\
\text { bly happen if ...? }\end{array}$ \\
\hline $\begin{array}{l}\text { 7. Effective feeling } \\
\text { management }\end{array}$ & $\begin{array}{c}\text { Oh, and in that case would that make our feeling of ... better/go away? } \\
\text { So, which behaviors do you think would be good ideas in order to express and } \\
\text { handle our... (feeling) ...? } \\
\text { Should we write them down separately, or draw pictures of them, } \\
\text { in order to be reminded in case we need to? }\end{array}$ \\
\hline
\end{tabular}

matched the socio-economic criteria of the experimental group-No intervention and control classrooms were in the same kindergarten complex of buildings.

\subsection{Training for Implementation}

The K-teachers of the students that formed our study's experimental group were also the facilitators of the program. This is a common practice concerning school-based prevention programs, as reported in some metanalyses (eg. Diekstra \& Gravesteijn, 2008; Durlak et al., 2011). Those teachers participated in: a) the initial thorough presentation, during which they were walked through the program's components and guidelines; b) three daily experiential workshops which took place every two months and during which they were guided on how to model and transfer the taught skills in the hidden curriculum; and c) monthly afternoon meetings with the coordinators, which served to ensure implementation fidelity and provide feedback, short-term progress reports, and support throughout the implementation of the program. The control group K-teachers did not receive any training.

\subsection{Implementation and Implementation Fidelity}

Whole-day program lessons were taught to the experimental group students by their teachers twice a week, while dissemination in both the formal and hidden 
curriculum was taking place through the suggested activities during every school-day till the next lesson was realized. Also, the letters to the students' families containing feedback and specific guidelines were sent during the lessons that required so, by the students' teachers.

Concerning implementation fidelity- "the degree to which teachers and other program providers implement programs as intended by the program developers" (Dusenbury et al., 2003: 240), which plays a critically important role in the evaluation of interventions (Durlak \& DuPre, 2008; O’Donnell, 2008) we took the following measures, similar to ones used in relevant studies (Brackett et al., 2012; Flannery et al., 2003; Mishara \& Ystgaard, 2006):

1) Clear implementation guidelines were included in the program's Teacher's Manual and analytically discussed during the initial presentation.

2) The detailed Lesson Guide offered explicit instructions on how to provide each lesson, including all the questions and expressions intended for use during the course and during the hidden curriculum, fully formulated. This fact not only strengthened the intervention's implementation fidelity but also helped the participating Greek K-teachers teach a subject which-although required as a target by the Greek formal curriculum as already mentionedthey usually feared to approach, since they had not received any relevant training during their studies. It should also be noted that every lesson of the "Steps for Life" curriculum is based on the knowledge acquired by the previous one, therefore making it very hard to proceed without following the given sequence.

3) All experimental group K-teachers were asked to complete an implementation and evaluation form after teaching each of the 50 curriculum's lessons. The forms which included questions concerning: a) students' concentration and interest; b) possible differences between the lesson as presented in the Lesson Guide and the way they it was realized; and c) realized activities (from the many offered in the Lesson Guide) were collected and discussed during the monthly meetings of the teachers' experimental groups.

4) The Prefecture School Counselor who had studied and approved the curriculum prior to the intervention and had also attended all training seminars and monthly meetings, visited all the intervention schools on a weekly basis during the whole school-year, in order to inspect the implementation procedure, making sure that the program was carried out as designed and providing feedback concerning the implementation fidelity.

\subsection{Measures}

The program's effectiveness was assessed by the use of a questionnaire designed to investigate the taught skills. Its first part consisted of items regarding demographics, school features, family status and parents' educational level. The second part (included in the Appendix), consisted of 96 items describing students' behaviors as exhibited in the school environment and assessed by their 
teachers. Out of those 96 items, 16 constituted the Coopersmith's \& Gilbert's (1982) Behavioral Academic Self-Esteem scale, translated and adapted in Greek (Kakouros \& Maniadaki, 2002), and 30 were adaptations from other skills' assessment scales for preschoolers (Kusché \& Greenberg, 1994; Merrell Preschool and Kindergarten Behavior Scale, 1994; Drexel Early Childhood Behavior, Shure, 2005). The questionnaire's total 96 items were categorized in the following $9 \mathrm{di}$ mensions (analytically presented in the Appendix):

A. Concentration of attention (10 items);

B. Participation/cooperation in the class (10 items);

C. Emotions' identification and management (18 items);

D. Verbal and physical aggressiveness control (14 items);

E. Victimization Control (5 items);

F. Self-esteem which consists of the B.A.S.E. 16 item-scale (Coopersmith \& Gilberts, 1982) translated by Kakouros and Maniadaki (2002);

G. Empathy (7 items);

H. Friendship skills (9 items);

I. Problem solving (7 items).

All the subscales used a 7 point Likert type ranking, with answers ranging from $1=$ never or almost never, to $7=$ always or almost always, except for the B.A.S.E. subscale (Coopersmith \& Gilbert, 1982) where a 5 point Likert scale is used, as indicated by its authors. The questionnaire ratings were designed to be given by the teachers.

\subsection{Data Collection}

The anonymous questionnaires-one for each student-were administered to the $79 \mathrm{~K}$-teachers of our sample students, in the beginning and at the end of the 2009-2010 school-year, namely two weeks prior to intervention and three weeks post intervention. The teachers were instructed to complete them within 7-10 days.

\subsection{Ethical Considerations}

The study protocol was approved by the Greek Ministry of Education and permission was granted by the Greek Pedagogical Institute (Ref. $\Phi 15 / 1415 / 152555 /$ Г1/21-12-2009). The license was granted on the condition of parents' consent on the completion of a questionnaire about their child. Indeed, the participating teachers were asked to acquire a written consensus from each student's parents, prior to the completion of the corresponding questionnaire.

\section{Statistical Methods-Data Analyses}

Quantitative variables were expressed as mean values (SD), while qualitative variables were expressed as absolute and relative frequencies. For the comparison of proportions chi-square and Fisher's exact tests were used. Student's t-tests were computed for the comparison of mean values. An exploratory factor analy- 
sis was performed in order to evaluate construct validity of the questionnaire. Principal component analysis (PCA) was chosen as extraction method using Varimax rotation. The cut-off point for factor loadings was 0.40 and for eigenvalues it was 1.00. The internal consistency of the questionnaire was analyzed with Cronbach's $\alpha$. Reliability equal to or greater than 0.70 was considered acceptable. Pearson correlations coefficients were used to explore the association among the questionnaire subscales. Repeated measurements analysis of variance (ANOVA) was conducted to evaluate the changes observed in questionnaire dimensions between the two study groups before and after the intervention. Also, in order to give an indication of the differences in questionnaire dimensions during follow up, effect sizes were also reported. Effect sizes of 0.2 - 0.5 are considered small, between $0.51-0.81$ moderate and over 0.8 are considered large. In order to control for effect of demographic and school related characteristics, a series of multiple linear regression analyses were conducted. The affected questionnaire dimensions were defined as dependent variables whereas the type of group (intervention vs. control) constituted the independent variable, after adjusting for gender, nationality, comprehension of the spoken language, ability of speaking the language, father's and mother's educational level, parents living together, family residing with grandparents, number of siblings, birth order, joint location of kindergarten with primary school, type of kindergarten (classic or all-day), number of students and baseline values. Adjusted regression coefficients $(\beta)$ with standard errors (SE) were computed from the results of the linear regression analyses. All reported $\mathrm{p}$ values are two-tailed. Statistical significance was set at $\mathrm{p}$ $<0.05$ and analyses were conducted using SPSS statistical software (version 19.0).

\section{Results}

Sample consisted of 998 students, of which 518 (51.9\%) were assigned in the intervention group and $480(48.1 \%)$ in the control group. Sample characteristics of both groups are presented in Table 2. The proportion of boys was $54.1 \%$ in the control group and $51.8 \%$ in the intervention one. Statistical difference between the two groups was present in mother's educational level, number of siblings, birth order, and kindergarten located in the same premises with primary school. An exploratory factor analysis with principal component method and with varimax rotation was conducted on the sample. Using the latent root criterion of retaining factors with Eigenvalues greater than 1.0, an eight-factor structure was identified, with the extracted factors explaining $67 \%$ of the total variance. Factor loadings of the rotated solution are shown in Table 3, with all factor loadings being more than 0.40 . Three items (C3, C5, C6) had loading less than 0.4 and were excluded. The proportion of variance explained by each factor was $11.7 \%$ for Concentration of attention, 10.3\% for Verbal/physical aggressiveness control, 9.3\% for Friendship skills, 8.4\% for Empathy, 7.6\% for Participation/collaboration in class, $7.1 \%$ for Emotions' identification and management, $6.6 \%$ for Vic- 
Table 2. Sample characteristics for the control and intervention group.

\begin{tabular}{|c|c|c|c|}
\hline & $\begin{array}{c}\text { Control group } \\
\mathrm{N}=480\end{array}$ & $\begin{array}{l}\text { Intervention group } \\
\qquad \mathrm{N}=518\end{array}$ & \\
\hline & $\mathrm{N}(\%)$ & $\mathrm{N}(\%)$ & $\mathrm{P}$ \\
\hline \multicolumn{4}{|l|}{ Gender } \\
\hline Boys & $259(54.1)$ & $267(51.8)$ & $0.482^{*}$ \\
\hline Girls & $220(45.9)$ & $248(48.2)$ & \\
\hline \multicolumn{4}{|l|}{ Nationality } \\
\hline Greek & $375(78.3)$ & $429(82.8)$ & $0.070^{*}$ \\
\hline Other & $104(21.7)$ & $89(17.2)$ & \\
\hline Age (years), mean (SD) & $4.6(0.5)$ & $4.6(0.5)$ & $0.368^{* *}$ \\
\hline \multicolumn{4}{|l|}{ Comprehension of the spoken language } \\
\hline None to moderate & $74(16.0)$ & $61(12.1)$ & $0.082^{*}$ \\
\hline Very good/Excellent & $388(84.0)$ & $442(87.9)$ & \\
\hline \multicolumn{4}{|l|}{ Ability of speaking the language } \\
\hline None to moderate & $113(24.5)$ & $117(23.4)$ & $0.700^{*}$ \\
\hline Very good/Excellent & $349(75.5)$ & $383(76.6)$ & \\
\hline \multicolumn{4}{|l|}{ Father's educational level } \\
\hline Primary to high school & $338(80.7)$ & $375(75.6)$ & $0.066^{*}$ \\
\hline 2-year college/University/Post-graduate studies & $81(19.3)$ & $121(24.4)$ & \\
\hline \multicolumn{4}{|l|}{ Mother's educational level } \\
\hline Primary to high school & $309(73.0)$ & $328(66.1)$ & $0.023^{*}$ \\
\hline 2-year college/University/Post-graduate studies & $114(27.0)$ & $168(33.9)$ & \\
\hline \multicolumn{4}{|l|}{ Parents living together } \\
\hline No & $24(5.1)$ & $18(3.5)$ & $0.240^{*}$ \\
\hline Yes & $451(94.9)$ & $491(96.5)$ & \\
\hline \multicolumn{4}{|l|}{ Family residing with grandparents } \\
\hline No & $379(83.7)$ & $404(82.8)$ & \\
\hline Yes & $74(16.3)$ & $84(17.2)$ & $0.719^{*}$ \\
\hline \multicolumn{4}{|l|}{ Number of siblings } \\
\hline None & $91(19.2)$ & $64(12.5)$ & $0.002^{*}$ \\
\hline One & $215(45.3)$ & $219(42.9)$ & \\
\hline Two more & $169(35.6)$ & $228(44.6)$ & \\
\hline \multicolumn{4}{|l|}{ Birth order } \\
\hline First & $265(55.9)$ & $247(48.3)$ & $0.031^{*}$ \\
\hline Second & $152(32.1)$ & $204(39.9)$ & \\
\hline Third or above & $57(12.0)$ & $60(11.7)$ & \\
\hline \multicolumn{4}{|l|}{$\begin{array}{l}\text { Kindergarten located in the same } \\
\text { premises with primary school }\end{array}$} \\
\hline No & $404(84.2)$ & $472(91.5)$ & $<0.001^{*}$ \\
\hline Yes & $76(15.8)$ & $44(8.5)$ & \\
\hline \multicolumn{4}{|l|}{ Kindergarten's operating hours } \\
\hline Classic & $345(71.9)$ & $395(76.6)$ & $0.092^{*}$ \\
\hline All-day & $135(28.1)$ & $121(23.4)$ & \\
\hline Number of students, mean (SD) & $16.8(3.0)$ & $16.5(3.4)$ & $0.141^{* *}$ \\
\hline
\end{tabular}


N. Kourmousi et al.

Table 3. Results from exploratory factor analysis.

\begin{tabular}{|c|c|c|c|c|c|c|c|c|}
\hline & \multicolumn{8}{|c|}{ Factor } \\
\hline & $\begin{array}{l}\text { Concentration } \\
\text { of attention }\end{array}$ & $\begin{array}{l}\text { Verbal/physical } \\
\text { aggressiveness } \\
\text { control }\end{array}$ & $\begin{array}{l}\text { Friendship } \\
\text { skills }\end{array}$ & Empathy & $\begin{array}{l}\text { Participation } \\
\text { /cooperation in } \\
\text { class }\end{array}$ & $\begin{array}{c}\text { Emotions' } \\
\text { identification/ } \\
\text { management }\end{array}$ & $\begin{array}{l}\text { Victimization } \\
\text { control }\end{array}$ & $\begin{array}{c}\text { Problem } \\
\text { solving }\end{array}$ \\
\hline A_1 & 0.81 & & & & & & & \\
\hline A_2 & 0.80 & & & & & & & \\
\hline A_3 & 0.79 & & & & & & & \\
\hline A_4 & 0.83 & & & & & & & \\
\hline A_5 & 0.74 & & & & & & & \\
\hline A_6 & 0.73 & & & & & & & \\
\hline A_7 & 0.41 & & & & & & & \\
\hline A_8 & 0.34 & & & & & & & \\
\hline A_9 & 0.76 & & & & & & & \\
\hline A_10 & 0.71 & & & & & & & \\
\hline D_1 & & 0.82 & & & & & & \\
\hline D_2 & & 0.73 & & & & & & \\
\hline D_3 & & 0.74 & & & & & & \\
\hline D_4 & & 0.82 & & & & & & \\
\hline D_5 & & 0.77 & & & & & & \\
\hline D_6 & & 0.78 & & & & & & \\
\hline D_7 & & 0.76 & & & & & & \\
\hline D_8 & & 0.84 & & & & & & \\
\hline D_9 & & 0.83 & & & & & & \\
\hline D_10 & & 0.81 & & & & & & \\
\hline D_11 & & 0.81 & & & & & & \\
\hline D_12 & & 0.54 & & & & & & \\
\hline D_13 & & 0.50 & & & & & & \\
\hline D_14 & & 0.71 & & & & & & \\
\hline H_1 & & & 0.41 & & & & & \\
\hline H_2 & & & 0.79 & & & & & \\
\hline H_3 & & & 0.84 & & & & & \\
\hline H_4 & & & 0.71 & & & & & \\
\hline H_5 & & & 0.68 & & & & & \\
\hline H_6 & & & 0.86 & & & & & \\
\hline H_7 & & & 0.69 & & & & & \\
\hline H_8 & & & 0.61 & & & & & \\
\hline H_9 & & & 0.45 & & & & & \\
\hline G_1 & & & & 0.56 & & & & \\
\hline G_2 & & & & 0.71 & & & & \\
\hline G_3 & & & & 0.71 & & & & \\
\hline G_4 & & & & 0.64 & & & & \\
\hline G_5 & & & & 0.57 & & & & \\
\hline G_6 & & & & 0.65 & & & & \\
\hline G_7 & & & & 0.70 & & & & \\
\hline
\end{tabular}


N. Kourmousi et al.

\section{Continued}

\begin{tabular}{|c|c|c|c|c|}
\hline B_1 & 0.62 & & & \\
\hline B_2 & 0.54 & & & \\
\hline B_3 & 0.70 & & & \\
\hline B_4 & 0.49 & & & \\
\hline B_5 & 0.41 & & & \\
\hline B_6 & 0.51 & & & \\
\hline B_7 & 0.50 & & & \\
\hline B_8 & 0.47 & & & \\
\hline B_9 & 0.48 & & & \\
\hline B_10 & 0.79 & & & \\
\hline C_1 & & 0.71 & & \\
\hline C_2 & & 0.66 & & \\
\hline \multicolumn{5}{|l|}{ C_3 } \\
\hline C_4 & & 0.72 & & \\
\hline \multicolumn{5}{|l|}{ C_5 } \\
\hline \multicolumn{5}{|l|}{ C_6 } \\
\hline C_7 & & 0.72 & & \\
\hline C_8 & & 0.72 & & \\
\hline C_9 & & 0.70 & & \\
\hline C_10 & & 0.34 & & \\
\hline C_11 & & 0.44 & & \\
\hline C_12 & & 0.41 & & \\
\hline C_13 & & 0.66 & & \\
\hline C_14 & & 0.52 & & \\
\hline C_15 & & 0.52 & & \\
\hline C_16 & & 0.40 & & \\
\hline C_17 & & 0.51 & & \\
\hline C_18 & & 0.50 & & \\
\hline E_1 & & & 0.73 & \\
\hline E_2 & & & 0.84 & \\
\hline E_3 & & & 0.84 & \\
\hline E_4 & & & 0.77 & \\
\hline E_5 & & & 0.81 & \\
\hline I_1 & & & & 0.80 \\
\hline I_2 & & & & 0.84 \\
\hline I_3 & & & & 0.84 \\
\hline I_4 & & & & 0.83 \\
\hline I_5 & & & & 0.78 \\
\hline I_6 & & & & 0.74 \\
\hline I_7 & & & & 0.40 \\
\hline
\end{tabular}

Note: Items are presented through their corresponding number. Full items' quotation is found in the Appendix.

timization control and $6.2 \%$ for Problem solving. All the questionnaire dimensions were significantly correlated with each other in the total sample. A signifi- 
cant correlation of them with the B.A.S.E. scale (Coopersmith \& Gilberts, 1982) was also found (Table 4). The results were similar when correlations were examined separately in control and intervention group $(\mathrm{p}<0.05)$.

Changes in questionnaire dimensions during the follow up period for the two study groups and Cronbach's $\alpha$, are presented in Table 5. Cronbach's a coefficient for all subscales was acceptable and over 0.7. At baseline, the control group had similar scores with the intervention group in all dimensions. After the intervention all children's scores in every dimension were greater, regardless of the group they belonged, thus all students' personal and social skills had improved significantly. Changes in questionnaire dimensions during follow up further confirmed its sensitivity to change over time. However, the degree of improvement was greater in the intervention group in all targeted skills except for Friendship skills. Effect sizes of the differences were for all subscales medium for the intervention group and low for the control group, with the exception of the Victimization control which had low effect sizes for both groups and Self-esteem which had medium effect sizes for both groups. Differences in the changes of the questionnaire dimensions between the two study groups after adjusting for sex, nationality, comprehension of spoken language, ability of speaking the language, parents' educational level and marital status, cohabitation with grandparents, number of siblings, birth order, kindergarten's location inside premises of primary school or not, the type of kindergarten (classic or all day), the number of students in classroom and the baseline values, are presented in Table 6. As indicated from the results of regression analysis, the intervention group children had significantly greater improvement of their personal and social skills post intervention, in comparison with controls, in all dimensions except Friendship skills.

\section{Discussion}

The purpose of the presented study was to evaluate the impact of the "Steps for

Table 4. Intercorrelations of questionnaire factors and correlations with self-esteem.

\begin{tabular}{|c|c|c|c|c|c|c|c|c|}
\hline & $\begin{array}{l}\text { Concentration } \\
\text { of attention }\end{array}$ & $\begin{array}{l}\text { Verbal/physical } \\
\text { aggressiveness } \\
\text { control }\end{array}$ & $\begin{array}{l}\text { Friendship } \\
\text { skills }\end{array}$ & Empathy & $\begin{array}{l}\text { Participation } \\
\text { /cooperation } \\
\text { in class }\end{array}$ & $\begin{array}{c}\text { Emotions' } \\
\text { identification/ } \\
\text { management }\end{array}$ & $\begin{array}{l}\text { Victimization } \\
\text { control }\end{array}$ & $\begin{array}{c}\text { Problem } \\
\text { solving }\end{array}$ \\
\hline $\begin{array}{c}\text { Verbal/physical } \\
\text { Aggressiveness control }\end{array}$ & 0.46 & & & & & & & \\
\hline Friendship skills & 0.49 & 0.39 & & & & & & \\
\hline Empathy & 0.69 & 0.56 & 0.47 & & & & & \\
\hline $\begin{array}{c}\text { Participation/cooperation } \\
\text { in class }\end{array}$ & 0.81 & 0.68 & 0.33 & 0.77 & & & & \\
\hline $\begin{array}{l}\text { Emotions' identification } \\
\text { and management }\end{array}$ & 0.62 & 0.77 & 0.23 & 0.65 & 0.77 & & & \\
\hline Victimization control & 0.38 & 0.52 & 0.31 & 0.29 & 0.42 & 0.43 & & \\
\hline Problem solving & 0.78 & 0.20 & 0.60 & 0.60 & 0.57 & 0.42 & 0.30 & \\
\hline Self-esteem & 0.82 & 0.31 & 0.67 & 0.70 & 0.68 & 0.52 & 0.41 & 0.86 \\
\hline
\end{tabular}

Note: All correlations are significant at $\mathrm{p}<0.001$ 
Table 5. Changes in questionnaire dimensions during the follow up period for the two study groups.

\begin{tabular}{|c|c|c|c|c|c|c|c|}
\hline & & Pre & Post & Change & & & \\
\hline Factor (Cronbach's $\alpha$ ) & Group & Mean (SD) & Mean (SD) & Mean (SD) & $\mathrm{P}^{* *}$ & Effect size & $\mathrm{P} \ddagger$ \\
\hline \multirow{3}{*}{$\begin{array}{l}\text { Concentration of } \\
\text { attention }(0.91)\end{array}$} & Intervention & $46.9(12.2)$ & $53.5(12.0)$ & $6.6(9.6)$ & $<0.001$ & 0.55 & $<0.001$ \\
\hline & Control & $48.2(13.3)$ & $52.2(13.0)$ & $4(9.1)$ & $<0.001$ & 0.31 & \\
\hline & $\mathrm{P}^{*}$ & 0.100 & 0.700 & & & & \\
\hline \multirow[t]{3}{*}{$\begin{array}{l}\text { Verbal/physical aggressiveness } \\
\text { control }(0.91)\end{array}$} & Intervention & $73.5(17.3)$ & $81.9(15.6)$ & $8.4(13.9)$ & $<0.001$ & 0.51 & $<0.001$ \\
\hline & Control & $75.3(16.9)$ & $79.2(15.4)$ & $3.9(13.5)$ & $<0.001$ & 0.24 & \\
\hline & $\mathrm{P}^{*}$ & 0.175 & 0.287 & & & & \\
\hline \multirow[t]{3}{*}{ Friendship skills (0.92) } & Intervention & $44.8(10.4)$ & $49.2(9.9)$ & $4.4(8.2)$ & $<0.001$ & 0.43 & 0.235 \\
\hline & Control & $45(11.3)$ & $48.9(9.9)$ & $3.9(8)$ & $<0.001$ & 0.37 & \\
\hline & $\mathrm{P}^{*}$ & 0.706 & 0.574 & & & & \\
\hline \multirow[t]{3}{*}{ Empathy (0.89) } & Intervention & $31.7(8.5)$ & $38.1(8.3)$ & $6.4(7.9)$ & $<0.001$ & 0.76 & $<0.001$ \\
\hline & Control & $32.6(7.8)$ & $36.2(8.5)$ & $3.5(8.0)$ & $<0.001$ & 0.43 & \\
\hline & $\mathrm{P}^{*}$ & 0.138 & $<0.001$ & & & & \\
\hline \multirow{3}{*}{$\begin{array}{c}\text { Participation } \\
\text { /cooperation in class }(0.90)\end{array}$} & Intervention & $50(11.5)$ & $56.1(11.2)$ & $6.1(9.6)$ & $<0.001$ & 0.54 & $<0.001$ \\
\hline & Control & $51.3(12.0)$ & $55.4(12.1)$ & $4.1(9.3)$ & $<0.001$ & 0.34 & \\
\hline & $\mathrm{P}^{*}$ & 0.117 & 0.023 & & & & \\
\hline \multirow[t]{3}{*}{$\begin{array}{l}\text { Emotions' identification } \\
\text { and management }(0.91)\end{array}$} & Intervention & $64.6(15.0)$ & $74.8(15.8)$ & $10.1(13.2)$ & $<0.001$ & 0.66 & $<0.001$ \\
\hline & Control & $66.6(17.5)$ & $71.6(16.5)$ & $5.1(13.5)$ & $<0.001$ & 0.30 & \\
\hline & $\mathrm{P}^{*}$ & 0.153 & 0.007 & & & & \\
\hline \multirow[t]{3}{*}{ Victimization control $(0.87)$} & Intervention & $28.7(6.4)$ & $30.5(6.0)$ & $1.8(5.2)$ & $<0.001$ & 0.28 & 0.011 \\
\hline & Control & $29.4(5.1)$ & $30.4(5.0)$ & $1.0(5.0)$ & 0.034 & 0.20 & \\
\hline & $\mathrm{P}^{*}$ & 0.095 & 0.586 & & & & \\
\hline \multirow[t]{3}{*}{ Problem solving (0.92) } & Intervention & $29.9(9.0)$ & $36(9.0)$ & $6.1(7.3)$ & $<0.001$ & 0.68 & $<0.001$ \\
\hline & Control & $30.7(9.7)$ & $34.1(9.5)$ & $3.4(8.3)$ & $<0.001$ & 0.36 & \\
\hline & $\mathrm{P}^{*}$ & 0.197 & $<0.001$ & & & & \\
\hline \multirow[t]{3}{*}{ Self-esteem (0.92) } & Intervention & $52.2(11.7)$ & $60(12.1)$ & $7.8(9.2)$ & $<0.001$ & 0.66 & 0.001 \\
\hline & Control & $53.2(11.0)$ & $60.1(12.0)$ & $6.9(8.9)$ & $<0.001$ & 0.60 & \\
\hline & $\mathrm{P}^{*}$ & 0.262 & 0.139 & & & & \\
\hline
\end{tabular}

${ }^{*} \mathrm{p}$-value for group effect; ${ }^{* *}$-value for time effect; $\ddagger$ Repeated measurements ANOVA. Effects reported include differences between the groups in the degree of change over the follow-up period

Life" (Kourmousi, 2012) personal and social skills K-curriculum by the use of a measure designed for assessing personal and social skills in K-students aged 4 to 6. The exploratory factor analysis identified the measure's eight-factor structure, with the extracted factors explaining $67 \%$ of the total variance and with all factor loadings being more than 0.40 . Cronbach's alpha for all the questionnaire subs- 
Table 6. Results of multiple linear regressions models for differences between the study groups with dependent variables the change in questionnaire dimensions and total score adjusted for all demographic factors.

\begin{tabular}{cccc}
\hline & $\beta^{*}$ & $\mathrm{SE}^{* *}$ & $\mathrm{P}$ \\
\hline Concentration of attention & 2.97 & 0.72 & $<0.001$ \\
Verbal/physical aggressiveness control & 3.44 & 1.04 & 0.001 \\
Friendship skills & 0.38 & 0.60 & 0.524 \\
Empathy & 2.99 & 0.59 & $<0.001$ \\
$\begin{array}{c}\text { Participation/ } \\
\text { cooperation in class } \\
\text { Emotions' identification } \\
\text { and management } \\
\text { Victimization control } \\
\text { Problem solving }\end{array}$ & 3.20 & 0.76 & $<0.001$ \\
$\quad$ Self-esteem & 4.35 & 1.00 & $<0.001$ \\
& 1.06 & 0.41 & 0.011 \\
\hline
\end{tabular}

*regression coefficient for the intervention versus the control group adjusted for gender, nationality, comprehension of spoken language, ability of speaking the language, father's and mother's educational level, parents living together, family cohabitating with grandparents, number of siblings, birth order, kindergarten being in the same premises with primary school, type of kindergarten (classic or all day) and number of students; ${ }^{* *}$ standard error.

cales was acceptable and ranged from $>0.92$ to $>0.87$. All the questionnaire dimensions were significantly correlated not only with each other but also with the B.A.S.E (Coopersmith \& Gilberts, 1982) scale as well, with the results remaining similar when correlations were examined separately in control and intervention group ( $\mathrm{p}<0.05)$. Intercorrelations with the B.A.S.E (Coopersmith \& Gilberts, 1982) scale provided further construct validity evidence for the newly developed scale. Changes in questionnaire dimensions during follow up further confirmed its sensitivity to change over time.

At baseline, the control group had similar scores with the intervention group in all dimensions. Regarding the post intervention performance, both groups significantly improved their skills in all dimensions. This shows that besides the socio-emotional improvement which occurs due to maturation, both the official K-curriculum and the "Steps for Life" curriculum seem to improve children's personal and social skills. However, the degree of change was found to differ significantly between the two groups, with the intervention group exhibiting higher improvement in all dimensions except Friendship skills. This fact confirmed our initial assumptions, namely that kindergarten students who attended the "Steps for Life" program would have a higher degree of improvement in the investigated personal and social skills, compared to those who had not attended the program.

Regarding intervention group's more increased concentration of attention, our investigation for similar improvements as a result of other interventions did not provide sufficient information. We attribute the improvement of the specific skill in a number of factors: a) a whole lesson in the beginning of the program is 
dedicated to teaching children how to deal effectively with distractions; b) students are encouraged to role-play situations ignoring distractions; c) games and ways of linking the taught knowledge are provided and practiced every day for a long period of time; d) instructions are given to teachers so that they can view each real life distraction as an opportunity for continuous learning for their students; e) the relevant letter to the parents provides simple instructions and encourages them to act as role models.

Concerning participation/cooperation in the class, which was also more increased in the experimental group students, we did not find it to be investigated in any similar study either. Regardless, enough studies and meta-analyses state the positive impact of such interventions on students' academic achievements in general (Ashdown \& Bernard, 2012; Brackett et al., 2012; Diekstra \& Gravesteijn, 2008; Durlak et al., 2011; National Research Council and Institute of Medicine, 2000; Payton et al., 2008; Zins, 2004).

Conversely, emotions' management and identification as well as emotional literacy enhancement were found to be widely targeted by similar interventions, most of which appeared to achieve their goals (Domitrovich, Cortes, \& Greenberg, 2007; Gansle, 2005; Hawkins, Smith, \& Catalano, 2004), thus confirming our finding that students' emotional skills can be improved by school-based programs.

In analogy, two also significantly more improved dimensions in our study that have to do with bullying prevention-namely control of verbal and physical aggression and control of victimization, turned out to constitute equally widely pursued and met targets by other researchers (Aiken et al., 1998; Catalano et al., 2004; McMahon et al., 2000; Powell \& Dunlap, 2009), indicating that socio-emotional enhancement school approaches can make a significant difference regarding violence and aggression.

As for self-esteem, which was also more increased in the experimental group students of our study, other skills developing interventions also appeared to enhance it, since studies and meta-analyses report "better self-image" or "more positive self-image" (Elias et al., 1991; Haney \& Durlac, 1998; O’Mara et al., 2006). This fact can only add to the widely held view that self-esteem can be improved in children and adults by learning socio-emotional skills.

Several social and emotional learning programs were also found to seek and succeed in ameliorating empathy (Committee for Children, 2002; Goldstein \& Glick, 1994; Webster-Stratton \& Hammond, 1997), confirming our findings and our conclusion, that prosocial behavior can be enhanced by appropriately designed long-term interventions in young children.

Another investigated and significantly higher improved dimension of our study, problem solving, appears to be one of the objectives and goals of only a few psychosocial education programs targeting preschool aged students. The "I can Problem Solve" program evaluation (Shure \& Spivack, 1982) also revealed similar positive results, indicating that problem solving can be taught and 
learned, even by kindergartners, through cognitive approaches (Shure \& Spivack, 2008).

Friendship skills were shown by our study to be equally improved in both groups post intervention. Social skills' development in general constitutes a conquered domain of several mental health promotion programs pursuing general social competence (Beelmann \& Lösel, 2006; Domitrovich, Cortes, \& Greenberg, 2007; Flannery et al., 2003; Mishara \& Ystgaard, 2006), but the specific friendship skills examined in our study did not result to higher improvement of the intervention group.

Finally, the significantly higher total score of the intervention children's in almost all investigated personal and social skills confirmed the findings of a growing number of studies and meta-analyses, which have documented the effectiveness of universal mental health promotion school programs (Bear et al., 2015; Durlak et al., 2011; Diekstra \& Gravesteijn, 2008; Durlak \& Wells, 1997; Payton et al., 2008; Wilson, Gottfredson \& Najaka, 2001).

Overall, our evaluation revealed a positive effect of the "Steps for Life" program in the development of life skills in kindergarten pupils, confirming that socio-emotional health promotion programs which have essential characteristics such as long duration, universal and systemic direction, motivation for critical thinking, respect and acceptance of the students' views and no "given" solutions and knowledge, and which also use parental involvement and dissemination of knowledge to the formal and the hidden curriculum, can enhance positive attitudes and skills and help prevent problem behaviors in children (Bear et al., 2015; Diekstra \& Gravesteijn, 2008; Durlak et al., 2011; Durlak \& Wells, 1997; Greenberg, Domitrovich, \& Bumbarger, 2001; Payton et al., 2008; Wilson, Gottfredson, \& Najaka, 2001).

\section{Limitations and Strengths}

"Steps for life" intervention appeared to enhance almost all the targeted and taught skills in the experimental group students of the presented study. A limitation of the study however, frequently occurring in the assessment of universal interventions is the use of the teachers-facilitators as observers and simultaneously evaluators of the performance of students (Ashdown \& Bernard, 2012; Brackett et al., 2012; Diekstra \& Gravesteijn, 2008; Domitrovich, Cortes, \& Greenberg, 2007; Durlak et al., 2011; Mishara \& Ystgaard, 2006; Vazsonyi, Belliston, \& Flannery, 2004). Unfortunately, budget restrictions do not often facilitate research that allows hiring external observers in schools; especially in our case, external observers performing their duties in the classes of the 79 K-teachers (both experimental and control ones) on a daily basis for a whole school-year, monitoring all students in order to be able to identify changes in their behaviors, would require an extremely high budget.

Another weak point is the fact that no questionnaires were administered to parents due to the cost that would be required for their administration and col- 
lection. Future evaluation studies of this program should include parents' assessment as well.

Finally, another weakness of this research is the lack of a follow-up study investigating the sustainability of its results.

Despite the above mentioned limitations in the "Steps for Life" program evaluation study, there are also several strengths and advantages: The satisfactory sample, the participation of $70 \%$ of the K-teacher population of a whole prefecture, the representativeness of the sample due to the representation of urban and rural and industrial areas, and the monitoring and continuous evaluation of the implementation of the intervention.

\section{Implications}

Our study contributes in the literature of children's socioemotional enhancement, by corroborating that personal and social skills can be taught and learned through structured and disseminated in the formal and hidden curriculum school interventions. Considering that in addition to their documented effectiveness mental health promotion school programs like "Steps for Life" seem to also have a cost-benefit advantage (Cohen \& Piquero, 2009), such relatively low-cost programs can become important aids for prevention policy designers; the few hundreds of euros needed to train the students of a classroom could ultimately save hundreds of thousands for the state, from mental disorders' treatment costs, from dealing with delinquent behavior and its results, and from the involvement of the penitentiary system. Therefore, we suggest that the implementation of such evaluated approaches which enhance children's critical thinking and social-emotional skills and contribute to their well-being should be generalized in schools.

We also wish to emphasize that such programs' evaluation leads to their own improvement; our study led us to improve the "Steps for Life" initial curriculum (Kourmousi, 2012) and add 4 more lessons in its latest edition (Kourmousi, 2013), targeting Friendship skills, Stress management, and Media resisting, as suggested by our participant K-teachers.

\section{Conclusion}

Our "Steps for Life" intervention met the goals we had set: almost all the targeted, taught and investigated skills-namely concentration of attention, cooperation, empathy, self-esteem, emotions' identification and management, physical and verbal aggressiveness control, victimization control, and problem solving, were significantly more improved in the experimental group students than the controls. These results confirm the findings that universal mental health promotion school-based K-programs which are systemic, have long duration, provide internal motivation, involve parents, and generalize the taught skills in the formal and hidden curriculum, can enhance students' socioemotional skills and help prevent problem behaviors (Bear et al., 2015; Durlak et al., 2011; Diek- 
stra \& Gravesteijn, 2008; Durlak \& Wells, 1997; Payton et al., 2008; Wilson, Gottfredson, \& Najaka, 2001).

Kindergarten education curricula are designed to improve the primary school readiness of youngsters and help them develop the skills which form the basis for future achievements, success, and psychosocial health. These curricula will have the power to exert even greater positive impact on the lives of children if they pursue the promotion of social-emotional learning together with the academic goals. As we add on our knowledge of the particularities of these efforts, it is of great importance for future investigators to identify the beneficial factors of each approach. The outcomes of such a procedure would save schools', teachers' and communities' uncertainty and consumption of time and money, and would make a substantial impact to the students' well-being.

\section{Acknowledgements}

Since the study was not financially supported by any sources, we would only like to thank all the K-teachers who participated in our study adopting a new approach and taking the time to complete a lengthy questionnaire for each of their student, in the beginning and in the end of the school year, without any financial gains.

\section{Author Contributions}

KM provided the initial guidelines for the designing of the study and took part in the manuscript writing. NK designed the study and created the questionnaire (Personal and Social Skills Scale for K-Students Aged 4-6) together with VK. She conducted the study, drafted the manuscript and together with the other authors reviewed its final form. MS organized the teachers' training, supervised the implementation of the program and took part in the manuscript reviewing. VK carried out the kindergarten teachers' experiential training. CT conducted the statistical analyses.

\section{Conflicts of Interest}

The authors declare no conflict of interest.

\section{References}

Aiken, L. S., West, S. G., Schwalm, D. E., Carroll, J. L., \& Hsiung, S. (1998). Comparison of a Randomized and Two Quasi-Experimental Designs in a Single Outcome Evaluation Efficacy of a University-Level Remedial Writing Program. Evaluation Review, 22, 207-244. https://doi.org/10.1177/0193841X9802200203

Arend, R., Gove, F. L., \& Sroufe, L. A. (1979). Continuity of Individual Adaptation from Infancy to Kindergarten: A Predictive Study of Ego-Resiliency and Curiosity in Preschoolers. Child Development, 50, 950-959. https://doi.org/10.2307/1129319

Ashdown, D. M., \& Bernard, M. E. (2012). Can Explicit Instruction in Social and Emotional Learning Skills Benefit the Social-Emotional Development, Well-Being, and Academic Achievement of Young Children? Early Childhood Education Journal, 39, 
397-405. https://doi.org/10.1007/s10643-011-0481-x

Bandura, A. (1997). Social Learning Theory. Upper Saddle River, NJ: Prentice Hall.

Barrett, P. M. (2004). FRIENDS for Life! For Children. Participant Workbook and Leaders Manual. Child and Adolescent Mental Health, 12, 58-65.

Battistich, V., Schaps, E., Watson, M., Solomon, D., \& Lewis, C. (2000). Effects of the Child Development Project on Students' Drug Use and Other Problem Behaviors. Journal of Primary Prevention, 21, 75-99. https://doi.org/10.1023/A:1007057414994

Bear, G. G., Whitcomb, S. A., Elias, M. J., \& Blank, J. C. (2015). SEL and Schoolwide Positive Behavioral Interventions and Supports. In J. Durlak, C. Domitrovich, R. Weissberg, \& T. Gullotta (Eds.), Handbook of Social and Emotional Learning (pp. 453-467). New York: The Guillford Press.

Beelmann, A., \& Lösel, F. (2006). Child Social Skills Training in Developmental Crime Prevention: Effects on Antisocial Behavior and Social Competence. Psicothema, 18, 603-610.

Belfield, C., Bowden, A. B., Klapp, A., Levin, H., Shand, R., \& Zander, S. (2015). The Economic Value of Social and Emotional Learning. Journal of Benefit-Cost Analysis, 6, 508-544. https://doi.org/10.1017/bca.2015.55

Bierman, K. L., Domitrovich, C. E., Nix, R. L., Gest, S. D., Welsh, J. A., Greenberg, M. T., Blair, C., Nelson, K. E., \& Gill, S. (2008). Promoting Academic and Social-Emotional School Readiness: The Head Start REDI Program. Child Development, 79, 1802-1817. https://doi.org/10.1111/j.1467-8624.2008.01227.x

Blair, C. (2002). School Readiness: Integrating Cognition and Emotion in a Neurobiological Conceptualization of Children's Functioning at School Entry. American Psychologist, 57, 111. https://doi.org/10.1037/0003-066X.57.2.111

Borba, M. (1989). Esteem Builders: A K-8 Self-Esteem Curriculum for Improving Student Achievement, Behavior and School Climate. Carson, CA: BL Winch \& Assoc./Jalmar Press.

Botvin, G. (1998). Life Skills Training: Promoting Health and Personal Development. Princeton, NJ: Princeton Health Press.

Botvin, G. J., Baker, E., Dusenbury, L., Tortu, S., \& Botvin, E. M. (1990). Preventing Adolescent Drug Abuse through a Multimodal Cognitive-Behavioral Approach: Results of a 3-Year Study. Journal of Consulting and Clinical Psychology, 58, 437. https://doi.org/10.1037/0022-006X.58.4.437

Brackett, M. A., Rivers, S. E., Reyes, M. R., \& Salovey, P. (2012). Enhancing Academic Performance and Social and Emotional Competence with the RULER Feeling Words Curriculum. Learning and Individual Differences, 22, 218-224. https://doi.org/10.1016/j.lindif.2010.10.002

Campbell, S. B. (1995). Behavior Problems in Preschool Children: A Review of Recent Research. Journal of child Psychology and Psychiatry, 36, 113-149. https://doi.org/10.1111/j.1469-7610.1995.tb01657.x

Catalano, R. F., Berglund, M. L., Ryan, J. A., Lonczak, H. S., \& Hawkins, J. D. (2004). Positive Youth Development in the United States: Research Findings on Evaluations of Positive Youth Development Programs. The Annals of the American Academy of Political and Social Science, 591, 98-124. https://doi.org/10.1177/0002716203260102

Cohen, M. A., \& Piquero, A. R. (2009). New Evidence on the Monetary Value of Saving a High Risk Youth. Journal of Quantitative Criminology, 25, 25-49. https://doi.org/10.1007/s10940-008-9057-3

Committee for Children (2002). Second Step: A Violence Prevention Curriculum, Pre- 
school/Kindergarten. Seattle: Committee for Children.

Coopersmith, S., \& Gilberts, R. (1982). Behavioral Academic Self-Esteem: A Rating Scale. Palo Alto, CA: Consulting Psychologists Press.

Denham, S. A., \& Burton, R. (1996). A Social-Emotional Intervention for At-Risk 4-Year-Olds. Journal of School Psychology, 34, 225-245. https://doi.org/10.1016/0022-4405(96)00013-1

Diekstra, R. F., \& Gravesteijn, C. (2008). Effectiveness of School-Based Social and Emotional Education Programmes Worldwide. Social and Emotional Education: An International Analysis (pp. 255-312).

http://www.fundacionbotin.org/89dguuytdfr276ed_uploads/EDUCACION/ANALISIS \%20INTERNACIONAL/2008/ingles\%202008/Results2008.pdf

Domitrovich, C. E., Cortes, R. C., \& Greenberg, M. T. (2007). Improving Young Children's Social and Emotional Competence: A Randomized Trial of the Preschool “PATHS” Curriculum. The Journal of Primary Prevention, 28, 67-91. https://doi.org/10.1007/s10935-007-0081-0

Durlak, J. A., \& DuPre, E. P. (2008). Implementation Matters: A Review of Research on the Influence of Implementation on Program Outcomes and the Factors Affecting Implementation. American Journal of Community Psychology, 41, 327-350.

https://doi.org/10.1007/s10464-008-9165-0

Durlak, J. A., \& Wells, A. M. (1997). Primary Prevention Mental Health Programs for Children and Adolescents: A Meta-Analytic Review. American Journal of Community Psychology, 25, 115-152. https://doi.org/10.1023/A:1024654026646

Durlak, J. A., Weissberg, R. P., Dymnicki, A. B., Taylor, R. D., \& Schellinger, K. B. (2011). The Impact of Enhancing Students' Social and Emotional Learning: A Meta-Analysis of School-Based Universal Interventions. Child Development, 82, 405-432. https://doi.org/10.1111/j.1467-8624.2010.01564.x

Dusenbury, L., Brannigan, R., Falco, M., \& Hansen, W. B. (2003). A Review of Research on Fidelity of Implementation: Implications for Drug Abuse Prevention in School Settings. Health Education Research, 18, 237-256. https://doi.org/10.1093/her/18.2.237

Elias, M. J., Gara, M. A., Schuyler, T. F., Branden-Muller, L. R., \& Sayette, M. A. (1991). The Promotion of Social Competence: Longitudinal Study of a Preventive School-Based Program. American Journal of Orthopsychiatry, 61, 409. https://doi.org/10.1037/h0079277

Englander-Golden, P., Jackson, J. E., Crane, K., Schwarzkopf, A. B., \& Lyle, P. S. (1989). Communication Skills and Self-Esteem in Prevention of Destructive Behaviors. Adolescence, 24, 481 .

Faggiano, F., Vigna-Taglianti, F. D., Versino, E., Zambon, A., Borraccino, A., \& Lemma, P. (2005). School-Based Prevention for Illicit Drugs' Use. The Cochrane Database of Systematic Reviews, 2, 1-79. https://doi.org/10.1002/14651858.CD003020.pub2

Flannery, D. J., Vazsonyi, A. T., Liau, A. K., Guo, S., Powell, K. E., Atha, H., Vesterdal, W. \& Embry, D. (2003). Initial Behavior Outcomes for the Peacebuilders Universal School-Based Violence Prevention Program. Developmental Psychology, 39, 292. https://doi.org/10.1037/0012-1649.39.2.292

Forness, S. R., Serna, L. A., Kavale, K. A., \& Nielsen, E. (1998). Mental Health and Head Start: Teaching Adaptive Skills. Education and Treatment of Children, 21, 258-274. http://www.jstor.org/stable/42940507

Gansle, K. A. (2005). The Effectiveness of School-Based Anger Interventions and Programs: A Meta-Analysis. Journal of School Psychology, 43, 321-341. 
https://doi.org/10.1016/j.jsp.2005.07.002

Geller, S. (1999). Al's pals: Kids Making Healthy Choices. Richmond, VA: Wingspan LLC.

Goldstein, A. P., \& Glick, B. (1994). Aggression Replacement Training: Curriculum and Evaluation. Simulation \& Gaming, 25, 9-26. https://doi.org/10.1177/1046878194251003

Gottfredson, G. D., Jones, E. M., \& Gore, T. W. (2002). Implementation and Evaluation of a Cognitive-Behavioral Intervention to Prevent Problem Behavior in a Disorganized School. Prevention Science, 3, 43-56. https://doi.org/10.1023/A:1014671310038

Gouridou, E. (2015). What Are the Important Emotional Intelligence Skills of a Good Teacher According to Parents and Students? MSc Thesis, Florina: University of Western Macedonia.

Greenberg, M. T., Domitrovich, C., \& Bumbarger, B. (2001). The Prevention of Mental Disorders in School-Aged Children: Current State of the Field. Prevention \& Treatment, 4, 1a. https://doi.org/10.1037/1522-3736.4.1.41a

Grossman, D. C., Neckerman, H. J., Koepsell, T. D., Liu, P. Y., Asher, K. N., Beland, K., Frey, K. \& Rivara, F. P. (1997). Effectiveness of a Violence Prevention Curriculum among Children in Elementary School: A Randomized Controlled Trial. JAMA, 277, 1605-1611. https://doi.org/10.1001/jama.1997.03540440039030

Hahn, R., Fuqua-Whitley, D., Wethington, H., Lowy, J., Crosby, A., Fullilove, M., Johnson, R., Liberman, A., Moscicki, E., Price, L., \& Snyder, S. (2007). Effectiveness of Universal School-Based Programs to Prevent Violent and Aggressive Behavior: A Systematic Review. American Journal of Preventive Medicine, 33, S114-S129.

https://doi.org/10.1016/j.amepre.2007.04.012

Haney, P., \& Durlak, J. A. (1998). Changing Self-Esteem in Children and Adolescents: A Meta-Analytical Review. Journal of Clinical Child Psychology, 27, 423-433. https://doi.org/10.1207/s15374424jccp2704_6

Hawkins, J. D., Smith, B. H., \& Catalano, R. F. (2004). Social Development and Social and Emotional Learning. In J. E. Zins, R. P. Weissberg, M. C. Wang, \& H. J. Walberg (Eds.), Building Academic Success on Social and Emotional Learning: What Does the Research Say? (pp. 135-150). New York: Teachers College Press.

Heckman, J. J., \& Lochner, L. J. (2000). Rethinking Myths about Education and Training: Understanding the Sources of Skill Formation in a Modern Economy Securing the Future: Investing in Children from Birth to College. New York: Russell Sage Foundation.

Hellenic Statistical Authority (2001). Characteristics of Dwellings-Households /2001. http://www.statistics.gr/en/statistics/-/publication/SAM05/2001

Jones, D. E., Greenberg, M., \& Crowley, M. (2015). Early Social-Emotional Functioning and Public Health: The Relationship between Kindergarten Social Competence and Future Wellness. American Journal of Public Health, 105, 2283-2290. https://doi.org/10.2105/AJPH.2015.302630

Kakouros, E., \& Maniadaki, K. (2002). Translation and Adaptation of the Behavioral Academic Self-Esteem Scale. In A. Stalikas, S. Triliva, \& P. Roussi (Eds.), Psychometric Tools in Greece (pp. 279-280). Athens: Ellinika Grammata. (In Greek)

Kappatou, A. (2014). Children in Adolescence, Parents in Crisis. Athens: Minoas Publications. (In Greek)

Kingston, L., \& Prior, M. (1995). The Development of Patterns of Stable, Transient, and School-Age Onset Aggressive Behavior in Young Children. Journal of the American Academy of Child \& Adolescent Psychiatry, 34, 348-358.

https://doi.org/10.1097/00004583-199503000-00021 
Kourmousi, N. (2012). Personal and Social Skills Training as a part of Health Education in Kindergarten. Doctoral Dissertation, Greece: University of Ioannina, (In Greek) https://www.didaktorika.gr/eadd/handle/10442/31671

Kourmousi, N. (2013). Steps for Life: Personal and Social Skills Curriculum for Kindergarten. Athens: Sokoli Publications. (In Greek)

Kusché, C. A., \& Greenberg, M. T. (1994). The PATHS Curriculum. Seattle, Washington DC: Development Research and Programs.

Landy, S. (2009). Pathways to Competence: Encouraging Healthy Social and Emotional Development in Young Children. Baltimore, MD: Paul H. Brookes Pub.

Lee, S., Aos, S., Drake, E., Pennucci, A., Miller, M., \& Anderson, L. (2012). Return on Investment: Evidence-Based Options to Improve Statewide Outcomes. Olympia: Washington State Institute for Public Policy.

McMahon, S. D., Washburn, J., Felix, E. D., Yakin, J., \& Childrey, G. (2000). Violence Prevention: Program Effects on Urban Preschool and Kindergarten Children. Applied and Preventive Psychology, 9, 271-281. https://doi.org/10.1016/S0962-1849(00)80004-9

Merrell, K. W. (1994). Preschool and Kindergarten Behavior Scales. Test Manual, Brandon: Clinical Psychology Publishing Company, Inc.

Merry, S., McDowell, H., Hetrick, S., Bir, J., \& Muller, N. (2004). Psychological and/or Educational Interventions for the Prevention of Depression in Children and Adolescents. The Cochrane Database of Systematic Reviews, 1, 1-103.

https://doi.org/10.1002/14651858.CD003380.pub2

Miller-Heyl, J., MacPhee, D., \& Fritz, J. J. (1998). DARE to Be You: A Family-Support, Early Prevention Program. Journal of Primary Prevention, 18, 257-285.

https://doi.org/10.1023/A:1024602927381

Mishara, B. L., \& Ystgaard, M. (2006). Effectiveness of a Mental Health Promotion Program to Improve Coping Skills in Young Children: Zippy's Friends. Early Childhood Research Quarterly, 21, 110-123. https://doi.org/10.1016/j.ecresq.2006.01.002

Moffitt, T. E., Caspi, A., Dickson, N., Silva, P., \& Stanton, W. (1996). Childhood-Onset versus Adolescent-Onset Antisocial Conduct Problems in Males: Natural History from Ages 3 to 18 Years. Development and Psychopathology, 8, 399-424. https://doi.org/10.1017/S0954579400007161

National Research Council and Institute of Medicine, Committee on Integrating the Science of Early Childhood Development (2000). From Neurons to Neighborhoods: The Science of Early Childhood Development. In J. P. Shonkoff, \& D. A. Phillips (Eds.), Board on Children, Youth and Families, Commission on Behavioural and Social Sciences and Education. Washington DC: National Academies Press.

O’Donnell, C. L. (2008). Defining, Conceptualizing, and Measuring Fidelity of Implementation and Its Relationship to Outcomes in K-12 Curriculum Intervention Research. Review of Educational Research, 78, 33-84.

https://doi.org/10.3102/0034654307313793

O’Mara, A. J., Marsh, H. W., Craven, R. G., \& Debus, R. L. (2006). Do Self-Concept Interventions Make a Difference? A Synergistic Blend of Construct Validation and Meta-Analysis. Educational Psychologist, 41, 181-206.

https://doi.org/10.1207/s15326985ep4103_4

Payton, J., Weissberg, R. P., Durlak, J. A., Dymnicki, A. B., Taylor, R. D., Schellinger, K. B., \& Pachan, M. (2008). The Positive Impact of Social and Emotional Learning for Kindergarten to Eighth-Grade Students: Findings from Three Scientific Reviews. Technical Report, Collaborative for Academic, Social, and Emotional Learning (NJ1). 
https://eric.ed.gov/?id=ED505370

Powell, D., \& Dunlap, G. (2009). Evidence-Based Social Emotional Curricula and Intervention Packages for Children 0 - 5 Years and Their Families (Roadmap to Effective Intervention Practices). Tampa, FL: University of South Florida.

Rampazzo, L., Mirandola, M., Davis, R. J., \& Xerri, R. (2016). Joint Action on Mental Health and Well-Being Situation Analysis and Recommendations for Action. DG SANCO, European Commission.

Rogers, C. (1998). The Interpersonal Relationship in the Facilitation of Learning. Taking Issue: Debates in Guidance and Counselling in Learning (pp 196-208). London; Routledge.

Shure, M. (2000). I Can Problem Solve: An Interpersonal Cognitive Problem-Solving Program. Champaign, Illinois: Research Press.

Shure, M. B. (2005). Drexel Early Childhood Behavior (DECB) Rating Scale. Philadelphia, PA: Drexel University.

Shure, M. B., \& Spivack, G. (1982). Interpersonal Problem-Solving in Young Children: A Cognitive Approach to Prevention. American Journal of Community Psychology, 10, 341-356. https://doi.org/10.1007/BF00896500

Shure, M. B., \& Spivack, G. (2008). The Problem-Solving Approach to Adjustment. Prevention in Human Services, 1, 87-103. https://doi.org/10.1300/J293v01n01_06

Sylva, K., Melhuish, E., Sammons, P., Siraj-Blatchford, I., Taggart, B., Smees, R., Dobson, A., Jeavons, M., Lewis, K., Morahan, M. and Sadler, S. (2004). The Effective Provision of Pre-School Education (EPPE) Project. Oxford: Institute of Education, University of London \& University of Oxford.

TACADE/Lions (1990). Skills for the Primary School Child. Manchester: TACADE.

Vazsonyi, A. T., Belliston, L. M., \& Flannery, D. J. (2004). Evaluation of a School-Based, Universal Violence Prevention Program: Low-, Medium-, and High-Risk Children. Youth Violence and Juvenile Justice, 2, 185-206. https://doi.org/10.1177/1541204003262224

Webster-Stratton, C., \& Hammond, M. (1997). Treating Children with Early-Onset Conduct Problems: A Comparison of Child and Parent Training Interventions. Journal of Consulting and Clinical Psychology, 65, 93.

Weissberg, R., Caplan, M., \& Sivo, P. (1989). A New Conceptual Framework for Establishing School-Based Social Competence Promotion Programmes. In L. S. Bond, \& B. E. Compas (Eds.), Primary Prevention and Promotion in the Schools (pp. 255-296). Newbury Park, CA: Sage. https://doi.org/10.1037/0022-006X.65.1.93

WHO (2001) Skills for Life (p. 8). Geneva: WHO.

Wilson, D. B., Gottfredson, D. C., \& Najaka, S. S. (2001). School-Based Prevention of Problem Behaviors: A Meta-Analysis. Journal of Quantitative Criminology, 17, 247-272. https://doi.org/10.1023/A:1011050217296

Wilson, S. J., \& Lipsey, M. W. (2007). School-Based Interventions for Aggressive and Disruptive Behavior: Update of a Meta-Analysis. American Journal of Preventive Medicine, 33, S130-S143. https://doi.org/10.1016/j.amepre.2007.04.011

Wilson, S. J., Lipsey, M. W., \& Derzon, J. H. (2003). The Effects of School-Based Intervention Programs on Aggressive Behavior: A Meta-Analysis. Journal of Consulting and Clinical Psychology, 71, 136. https://doi.org/10.1037/0022-006X.71.1.136

Zins, J. E. (Ed.) (2004). Building Academic Success on Social and Emotional Learning: What Does the Research Say? New York: Teachers College Press. 
$\Delta \mathrm{E} \Pi \Sigma$ (Cross-Curricular Program Framework) (2001). Pedagogical Institute, Government Gazette 1366 /18-10-2001, B. (In Greek)

$\triangle$ ЕПП $\Sigma$ (Cross-Curricular Program Framework) (2013). Pedagogical Institute, Gov. 303 and 304 /13-3-2003, B, volumes A and B. (In Greek) 


\section{Appendix}

Personal and Social Skills Scale for K-Students Aged 4-6 (Kourmousi, N. \& Koutras V. in Kourmousi, 2012):

\section{Guidelines for $K$-teachers}

The Personal and Social Skills Scale for Preschool Students Aged $4-6$ is a teacher-rated scale designed to evaluate students' skills as expressed by their behaviors at school environment. You are asked to evaluate the student's performance regarding each of the following statements, using the 7-point Likert scale, in order to indicate the frequency with which the child expresses a behavior. How often does the child exhibit the following patterns of behavior? (i: never or almost never, ii: very rarely, iii: rarely, iv: sometimes, v: often, vi: very often, vii: always or almost always)

\section{A. CONCENTRATION OF ATTENTION}

How often does the child

1) Work with zeal

2) Work/Keep on working despite any distractions

3) Concentrate on the lesson and on the various activities

4) Persist in working on his/her assignments

5) Pay attention during the lesson

6) Maintain attention for sufficient time (for about 15 minutes)

7) Interrupt the discussion or the activities taking place when he/she wants something, without wondering whether it is appropriate or not

8) Interrupt politely

9) Actively participate in the classroom activities

10) Actively participate in the classroom discussions

B. PARTICIPATION /COOPERATION IN CLASS

How often does the child

1) Let his/her classmates speak

2) Listen carefully to others

3) Await his/her turn to speak

4) Accept assignments willingly and without complaining

5) Play in a fair manner

6) Await his/her turn to engage in activities

7) Respect the rules which have been set

8) How often is the child good in cooperating with the other children

9) Take into account the preferences of the other children during play-time or activities

10)Meet the level of his/her class

C. EMOTIONS' IDENTIFICATION AND MANAGEMENT

How often does the child

1) Recognize and name his/her own feelings

2) Recognize and name others' feelings

3) Hide his/her feelings 
4) Talk about his/her feelings

5) Feel safe at school

6) Seek to win in a stubborn way

7) Get excessively bothered when he/she loses

8) Get easily bothered when he/she encounters difficulties during work

9) Get easily upset when things don't work the way he/she wants

10)Find ways to calm himself/herself when he/she gets angry and upset

11)Get impatient and cannot wait

12)Try to find ways to handle waiting

13) Grab other children's toys

14) Remain upset for quite some time

15)Show obstinacy (stubbornness)

16) Act impulsively

17)Lose temper during disputes

18) Get angry when he/she disagrees

D. ABILITY TO CONTROL VERBAL AND PHYSICAL AGGRESSIVENESS

How often does the child

1) Threaten to harm a classmate in order to get what he/she wants

2) Tell classmates that he/she will not play with them unless they do what he/she wants

3) Not let a classmate be with him/her and his/her friends when angry with the child

4) Verbally threaten that he/she will hurt other children

5) Yell at others during a dispute

6) Taunt/mock his/her classmates

7) Destroy things when upset

8) Push the other children

9) Kick or beat the others

10)Cause pain to other children in some other way

11) Choose to fight and collide

12)Avoid conflicts by backing down

13)Avoid conflicts by choosing to use ignoring as a strategy

14) Choose to be involved in quarrels

E. ABILITY TO CONTROL VICTIMIZATION

How often does the child

1) Get taunted/mocked by other children

2) Get threatened

3) Get bullied

4) Get pushed

5) Get beaten or pain inflicted in other ways

F. SELF-ESTEEM (Coopersmith \& Gilberts, 1982 B.A.S.E. SCALE) 16 items 5-point Likert type with answers ranging from Never to Always

G. EMPATHY 
How often does the child

1) Take into consideration the feelings and preferences of other children

2) Show compassion for others

3) Show interest in peers

4) Help classmates

5) How often is the child good at sharing his/her toys with classmates

6) Say nice things about other children

7) Do nice things for other children

H. FRIENDSHIP SKILLS

How often does the child

1) How often is the child likable among peers

2) Choose to play alone

3) Watch the other children play but avoids to play with them

4) Seem too timid

5) Seem too shy

6) Withdraw from the other children

7) Enter groups of friends with ease

8) Create new friendships

9) Maintain friendships

PROBLEM SOLVING

How often does the child

1) Complete the assigned activities

2) Overcome obstacles by himself/herself

3) Try to solve a problem that arises, by himself/herself

4) Find alternative solutions to problems

5) Consider/explore consequences

6) Suggest solutions to problems that arise in class

7) When claiming something, he/she does it in a decisive manner

Note: Permission to use the Personal and Social Skills Scale for K-Students Aged 4 - 6 is granted for educational purposes only, upon request. Please note that we suggest that items C3, C5 and C6 should be excluded. 
Submit or recommend next manuscript to SCIRP and we will provide best service for you:

Accepting pre-submission inquiries through Email, Facebook, LinkedIn, Twitter, etc. A wide selection of journals (inclusive of 9 subjects, more than 200 journals)

Providing 24-hour high-quality service

User-friendly online submission system

Fair and swift peer-review system

Efficient typesetting and proofreading procedure

Display of the result of downloads and visits, as well as the number of cited articles Maximum dissemination of your research work

Submit your manuscript at: http://papersubmission.scirp.org/

Or contact ce@scirp.org 